\title{
TERMOPLASZTIKUS ELASZTOMEREK TÉRHÁLÓSÍTÁSA
}

\section{CROSSLINKING OF THERMOPLASTIC ELASTOMERS}

Gergely Attila Levente

Sapientia EMTE, Marosvásárhelyi Kar, Gépészmérnöki Tanszék, Cím: 540485, Románia, Marosvásárhely/Koronka, 1C.; 540485 Tîrgu Mureş, O.p. 9, C.p. 4, Telefon: +40 265206 210, agergely@ms.sapientia.ro

\begin{abstract}
A novel thermoplastic elastomer has been reported in the literature recently, containing polyalloocimene as hard, or glassy, blocks and polyisobutylene as soft blocks. These novel materials show promising potentials both in rubber- and biomedical applications. One of the critical characteristics that has been investigated and presented here is the cross-link ability of these materials. The present work proves that the new thermoplastic elastomers can be crosslinked using either sulfur or peroxide based curing systems.
\end{abstract}

Keywords: thermoplastic elastomers, butyl rubber, cross-linking, curing, peroxy.

\section{Összefoglalás}

Egy új termoplasztikus elasztomer elöállításáról számoltak be a szakirodalomban a közelmúltban, mely polialloocimin üveges blokkokat és poliizobutilén elasztikus blokkokat tartalmaz. Ezek az új anyagok nagy potenciállal rendelkeznek a gumi és az orvostechnikai eszközgyártás terén. Az egyik feltétele ezen anyagok használatának a fent említett iparágakban a vulkanizálhatóságuk. A jelen dolgozatban bemutatott eredmények alapján az új termoplasztikus elasztomerek vulkanizálása lehetséges úgy kén alapú, mint peroxid alapú vulkanizációs rendszerekkel.

Kulcsszavak: termoplasztikus elasztomer, butil gumi, térhálósitás, vulkanizáció, peroxid.

\section{Bevezetés}

A termoplasztikus elasztomerek (TPE) a polimerek egy különleges csoportja, mely rendelkezik elasztikus és plasztikus tulajdonságokkal, így a mechanikai tulajdonságai befolyásolhatók az anyag összetételével.[1,2] A szakirodalomban a közelmúltban jelentették egy új izobutilén alapú, alloocimén üveges blokkokat tartalmazó, termoplasztikus elasztomer előállítását izobutilén és alloocimin élő kopolimerizációjával. [3-5] Az új termoplasztikus elasztomereket kitünő mechanikai tulajdonságaik [4,5] és biokompatibilitásuk [6-8] miatt a gumi iparban, valamint az orvostudományban bioanyagként lehetne felhasználni.

A jelen dolgozat ezen új anyagok vulkanizációját, vizsgálja kén és peroxid rendszerekkel.

\section{Használt anyagok és metódusok}

\subsection{Anyagok}

A használt poliizobutilén (PIB) alapú TPE-ek a szakirodalomban jelentett eljárással készültek.[3-5] Az 1. táblázat bemutatja a vizsgált TPE-ket. Rövidített elnevezésük a polimer szerkezetét, molekulatömegét és az alloocimén súlyszázalékát tükrözi, $\mathrm{M}_{\mathrm{n}}$ a polimerek molekulatömege, az alloocimén 
tömegszázalék a molekulatömeg eloszlást adja meg. Kontroll anyagként az Exxon Mobil által forgalmazott BrButyl2222 és ClButyl1066 volt használva.

1. táblázat. A használt termoplasztikus elasztomerek jellemzö paraméterei.

\begin{tabular}{|c|c|c|c|}
\hline Minta & $\begin{array}{c}\mathrm{M}_{\mathrm{n}} \\
(\mathrm{g} / \mathrm{mol})\end{array}$ & $\begin{array}{c}\text { Allo } \\
\text { tömeg } \\
\%\end{array}$ & $\begin{array}{c}\text { Polimer } \\
\text { struktúra }\end{array}$ \\
\hline $\mathrm{T}(195) 25$ & 195000 & 25 & Triblokk \\
\hline $\mathrm{Te}(347) 24$ & 347000 & 24 & Tetrablokk \\
\hline
\end{tabular}

\subsection{Keverés}

A használt anyagokat 60 phr (parts per hundered rubber, gumiiparban használatos mértékegység) korommal (Cabot, Black Pearl, BET $\left.\sim 110 \mathrm{~m}^{2} / \mathrm{g}\right)$, egy $80 \mathrm{~cm}^{3}$ Brabender belsőkeverőgéppel kevertük (Brabender, Intelli-Torque Plasti-Corder, USA), $125^{\circ} \mathrm{C}$ hömérsékleten, $60 \mathrm{rot} / \mathrm{min}$ fordulatszámon, 0,7 kitöltési faktor használatával. A keverési idő 3 x 5 perc volt. A vulkanizáláshoz szükséges adalék anyagok hozzáadása ú.n. mikro-keverési technikával történt. Ez a keverési technika magába foglalja az adalékanyagok hozzáadását egy polimer filmhez, majd a polimer film öszszehajtogatását és magas nyomás segítségével $100^{\circ} \mathrm{C}$-on újra polimer filmmé való alakítását. A megfelelő homogenitás elérése érdekében az összehajtogatást és filmmé alakítást 15-17 alkalommal kellett megismételni.

\subsection{Vulkanizációs folyamat vizsgálata}

A kevert minták vulkanizálási tulajdonságainak vizsgálatára egy Alpha Technologies Rheometer MDR 2000 berendezést használtunk. A mérésekhez megközelítőleg $5 \mathrm{~g}$ minta volt szükséges $160^{\circ} \mathrm{C}$ fokon $7 \%$ megnyúlási érték mellett. Egy vizsgálat időtartama 30 perc volt.

\section{Eredmények}

\subsection{Térhálósítás kénnel}

A 2. táblázat tartalmazza a vulkanizációs recepteket. A TPE mintákban a térhálósítás az allil-helyzetü hidrogén atom által jön létre, a butil elasztomereknél a klór és a bróm atomokon keresztül.

2. táblázat. Kén alapú vulkanizációs recept.

\begin{tabular}{|c|c|c|}
\hline & $\begin{array}{c}\text { T(195)25/ } \\
\text { Cl-butil/ } \\
\text { Br-butil* } \\
\text { [phr] }\end{array}$ & $\begin{array}{c}\text { Te(347)24 } \\
\text { [phr] }\end{array}$ \\
\hline Polimer & 100 & 100 \\
\hline Korom & 60 & 60 \\
\hline Kén & 1.5 & 2.4 \\
\hline ZnO & 5 & 8 \\
\hline Sztearinsav & 1 & 1.6 \\
\hline MBT & 0.5 & 0.816 \\
\hline TMTD & 1 & 1.76 \\
\hline
\end{tabular}

MBT - 2-merkaptobenzotiazol

TMTD - tetrametil tiurám diszulfid

*Mindhárom anyag azonos kompoziciójú.

A vulkanizáltsági görbék, 1. ábra, hasonlóak mindkét TPE esetén. Látható, hogy a vulkanizálási sebesség a 2 és 8 perc közti szakasz iránytényezője, és a maximális elért nyomaték, $\sim 15 \mathrm{dNm}$, azonos annak ellenére, hogy a Te(347)24 mintánál több kén volt használva. Ez a jelenség a mindkét anyagban jelenlevő megközelítőleg azonos menynyiségű kettőskötésnek tudható be. Mindkét kontroll anyag gyorsabb vulkanizációs sebességet mutat a vizsgált TPE-hez képest, viszont a maximálisan elért nyomatékok alacsonyabbak, jelezve, a vulkanizációs szint ezekben az anyagokban alacsonyabb.

A T(195)25 minta szakítószilárdsága térhálósítás előtt $\sim 12 \mathrm{MPa}$ volt $\sim 450 \%$ megnyúlás mellett, míg a T(347)24 mintáé $\sim 18 \mathrm{MPa}, \sim 500 \%$ szakadási nyúlás mellett. 


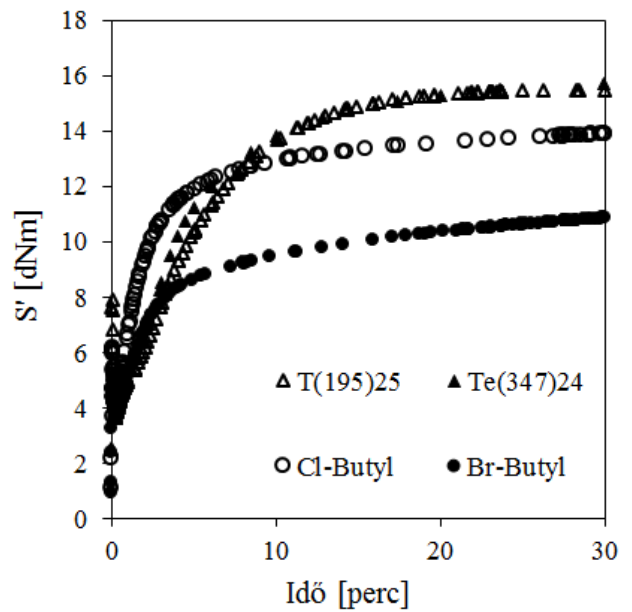

1. ábra. A TPE és a kontroll anyagok vulkanizáltsági görbéi.

A különbség a két minta molekula- tömegének különbségéböl adódik, illetve az ebböl adódó gyengébb polimer-töltőanyag kölcsönhatásnak, mely alacsonyabb szintü megerősítést jelent. Vulkanizáció után a vizsgált TPE-k szinte megegyező szakítószilárdsági görbét produkáltak: $\sim 5 \mathrm{MPa}$ modulusz, $\sim 10 \quad \mathrm{MPa}$ szakítószilárdság $\sim 200 \%$ megnyúlás mellett.

Ezzel szemben a kontroll anyagok közül a Cl-butil $\sim 1 \mathrm{MPa}$ moduluszt és $12 \mathrm{MPa}$ szakítószilárdságot mutat $300 \%$ megnyúlás mellett, míg a Br-butil $\sim 1 \mathrm{MPa}$ moduluszt, $\sim 22 \mathrm{MPa}$ szakítószilárdságot 400 \% megnyúlás mellett. A kontroll anyagok szakítószilárdságának különbsége annak tudható be, hogy a Br-butil $\sim 1 \%$ brómot tartalmaz, míg a Cl-butil 1,26\% klórt. Ennek tulajdonítható a gyorsabb vulkanizálás is a Cl-butil esetén (annak ellenére, hogy a bróm reaktívabb), illetve a magasabb vulkanizációs szint, vagyis egy sürübb térhálós szerkezet kialakulása. A sürü térhálós szerkezet alacsonyabb szakítószilárdságot eredményez, mivel ebben az esetben a láncok mobilitása jelentősen lecsökken.

A vizsgált termoplasztikus elasztomerek magas modulusza, relatíve alacsony szakítószilárdsága és magas nyomatéka a vulkanizáltsági görbén egy nagyon sürü térhálós szerkezetet feltételez. Ezt alátámasztja a nagy mennyiségü, 24\% ( 24 mol\%), kettőskötés jelenléte, amelyek nagyrésze koncentrálva van a fázisszeparáció miatt. Ezeket figyelembe véve levonhatjuk a következtetést, hogy a TPE minták nagy sürüségü, de heterogén térhálós szerkezettel rendelkeznek, ezzel szemben a kontroll minták térhálós szerkezete kisebb sürüségü és homogén.

\subsection{Térhálósítás peroxiddal}

Bizonyos alkalmazásoknál a kén használata nem lehetséges a térhálósítási folyamat megvalósításához, ezért gyakran peroxidot használnak. Csak peroxid használata a butilgumi térhálósításához nem alhalmas, mivel degradáció lép fel. [9] Viszont a dikumil-peroxid (DKP) és bisz-maleimid (BMI) kombinációja használható a halogénbutil térhálósítására. [10] A T(347)23,7 Megvizsgáltuk a 60 phr korommal megerösített TPE minta térhálósítási lehetőségét

3. táblázat. Peroxid alapú térhálósitási recept.

\begin{tabular}{|c|c|c|}
\hline Minta* & $\begin{array}{c}\text { DKP } \\
{[\mathrm{phr}]}\end{array}$ & $\begin{array}{c}\text { BMI } \\
{[\mathrm{phr}]}\end{array}$ \\
\hline P6.7 & 6.7 & -- \\
\hline BMI3.2 & -- & 3.2 \\
\hline BMI6.4 & -- & 6.4 \\
\hline P6.7_BMI3.7 & 6.7 & 3.7 \\
\hline P1.6_BMI3.4 & 1.6 & 3.4 \\
\hline P1.6_BMI6.4 & 1.6 & 6.4 \\
\hline
\end{tabular}

DKP - Dikumil-peroxid

BMI - Bisz-maleimid

*Mintanév magyarázat: $\mathrm{P}$ jelzí a DKP használatát.

A térhálósítási receptek a 3. táblázatban találhatók. A vulkanizálási recept fejlesztésekor szisztematikusan tanulmányoztuk a recept egyes elemeinek hatását a vulkanizálási folyamatra. Viszonyítási alapként az adalékanyagot nem tartalmazó korommal megerősített minta vulkanizációs görbéjét vettük. Kizárólag DKP, 6,7 phr, használatakor degradáció lépett fel. Kizárólag a BMI 
hatását tanulmányozva két esetet vizsgáltunk, 3,2 vagy 6,4 phr BMI hozzáadásával. Mindkét esetben a maximálisan elért nyomaték reál komponense (S') 5,5 dNm volt. Vagyis a használt BMI mennyiség nincs hatással a térhálósítási folyamatra. A referencia anyag maximális $\mathrm{S}^{\prime} 4,5 \mathrm{dNm}$. Öszszehasonlítva a mért eredményeket a referencia anyagéval látható, hogy nem történt számottevő vulkanizáció.

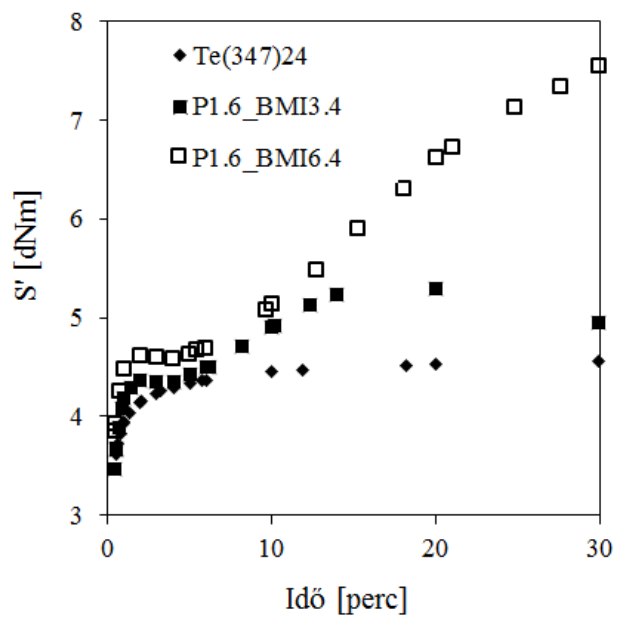

2. ábra. Vulkanizáltsági görbék peroxid vulkanizációs rendszer használata esetén.

6,7 phr DKP és 3,7 phr BMI használatakor szintén degradáció lépett, habár a BMI jelenléte késleltette a degradációt. A 2. ábrán látható, hogy abban az esetben, mikor 1,6 phr. DKP-t használtunk 3,4 phr BMI jelenlétében degradáció jelentkezett, de csak 20 perc után. A BMI mennyiség növelése 6,4 phr-re viszont megakadályozta a degradációt és beindította a vulkanizációs folyamatot. A maximális $\mathrm{S}^{\prime}, \sim 8 \mathrm{dNm}$, közel fele a kénnel végzett vulkanizációnak.

\section{Következtetések}

A jelen dolgozatban bemutatott eredmények igazolják, hogy az új TPE-k tri- és tetrablokk struktúrával térhálósíthatók kén és peroxid alapú vulkanizációs rendszerekkel.

\section{Szakirodalmi hivatkozások}

[1] XML on-line corrected version http://goldbook.iupac.org (2006-) created by M. Nic, J. Jirat, B. kosata, updates compiled by A. Jenkins.

[2] Orilall, M.C.; Wiesner, U. Chem. Soc. Rev. 2011, 40, 520-535.

[3] Puskas, J.E.; Gergely, A.L.; Kaszas,G.: Controlled/Living Carbocationic Copolymerization of Isobutylene with Alloocimene, $J$. Polym. Sci. Part A: Polym. Chem., 2013, 51, 29-33.

[4] Gergely, A.L.; Puskas, J.E.: Synthesis and Characterization of Thermoplastic Elastomers with Polyisobutylene and Polyalloocimene Blocks J. Polym. Sci. Part A: Polym. Chem., 2015, 53, 1567-1574.

[5] Gergely, A.L.: Doktori Disszertáció, The University of Akron, Akron, OH, USA, 2014.

[6] US FDA, 2004. TAXUS ${ }^{\mathrm{TM}}$ Express $^{2 \mathrm{TM}}$ paclitaxel-eluting coronary stent system. PO30025.

[7] Ranade, S.V.; Miller, K.M.; Richard, R.E.; Chan, A.K.; Allen, M.J.; Helmus, M.N. J. Biomed. Mater. Res. Part A 2004, 71(4), 625.

[8] Puskas, J.E.; Chen, Y.; Dahman, Y.; Padavan, D. J.: Polym. Sci. Part A: Polym. Chem. 2004, 42, 3091-3109.

[9] Thomas, D.K. Trans. Faraday Soc. 1961, 57, 511-517.

[10] Fusco, J.V.: General Purpose Elastomers Isobutylene-based Elastomers In Basic Elastomer Technology, Rubber Division, ACS: Akron, 2001, pp. 312-346. 